\title{
Difference of learning mathematics between open question model and conventional model
}

\author{
Ahmad Afandi \\ IKIP PGRI Jember, Jember, Indonesia, 68121 \\ *Corresponding author: aafandi832@gmail.com
}

\section{ARTICLE HISTORY}

Received May 13, 2018

Revised June 10, 2018

Accepted July 3, 2018

\section{KEYWORDS}

Results of learning mathematics Model of open learning problems Conventional learning model

\begin{abstract}
Open learning model as well as conventional learning model is a learning model that is able to enable students in acquiring knowledge and learning experiences. The purpose of this research is to know the difference of learning result between students taught by using model of open matter problem and conventional learning model on the subject of wake up space. This research was conducted at SMP Al Badri Arjasa Jember in February 2018. The research subjects were 70 students in two classes namely class VIII - A and class VIII - B. This research uses experimental design that is, one experiment class and one control class. The results obtained in the study are learning outcomes using open-ended learning model and conventional learning model. T-test conducted shows that there are differences. Average learning outcomes of experimental class students after treatment was 69.657 while the control class learning outcome was 56.886 . The conclusion that can be drawn from data analysis and discussion result is difference of student learning result by using model of open learning problem with conventional learning model, and model of open learning problem is suitable to be applied to the subject of student room of SMP Al Badri Arjasa Jember.
\end{abstract}

This is an open access article under the CC-BY-SA license.

\section{INTRODUCTION}

Efforts to develop the potential of students as well as in improving the quality of education, especially mathematics education many done, even continuously strived, but the quality of education achieved not in accordance with the desired expectations. Based on the results of interviews with some teachers who have experienced as a teacher of mathematics, especially Junior High School teacher Al Badri ArjasaJember, that in teaching mathematics students are expected not only to remember, understand, and apply course, but students are also expected to analyze and evaluate information. Therefore, in teaching mathematics teachers do not transfer knowledge to students but how teachers direct students to build new knowledge according to their own thinking.

Soedjadi (2000: 6) argues that "a teacher will be able to use mathematics to bring students to a defined goal, if students can understand well the mathematics that will be used as a vehicle for education". If the teacher's understanding of mathematics is not good enough to ensure that the use of mathematics as a vehicle of education will also not work as expected.

Based of the description above that goal of mathematics education the role of teachers is very important. With the development of the times many emerging models of learning that exist in schools. From the conventional learning model, it develops into an interesting and non-boring learning model. But there are still many teachers or teaching staff who use conventional learning models in learning activities. This could mean that teachers or faculty can only use conventional learning models and do not seek to find learning models that may be better and more suitable for their students, or it may be just a conventional learning model that is suitable for students.

In the learning process, it is necessary to give the students the opportunity to think freely according to their interests and abilities. For that the use of learning model is very important for the success of a teaching and learning activities. One of the learning models that can be used is the open learning model. With the open learning model, it is expected that the classroom activity will be full of mathematical ideas and ultimately can improve the creativity and learning outcomes and can develop students' self potential.

The open-ended learning model is a learning model that presents a problem that has a correct final solution or answer of more than one answer and provides an opportunity for students to answer the problem with various strategies and ways that are believed to fit their abilities. The purpose of the open-ended learning model is not to get an answer but to emphasize how to arrive at an answer. Thus there is not only one approach or method in getting the right answer, but some or many of the "openness" traits.

Hudojo (1990: 40) suggests that "mathematics is a tool for developing ways of thinking". This means that the open-ended learning model that gives students the opportunity to solve problems in accordance with their ability to think in the learning process and mathematics learning is better than with the conventional learning model that emphasizes teacher-centered learning activities, so that students are more passive and students can not develop his way of thinking. 


\section{METHOD}

This study included the type of experimental research. In experimental research there are two variables that are free or treatment and control. Independent variable or treatment in this research is learning by using learning model about tebuka, while control variable in this research is learning by using conventional learning model. The study population is all students of class VIII consisting of four classes and taken two

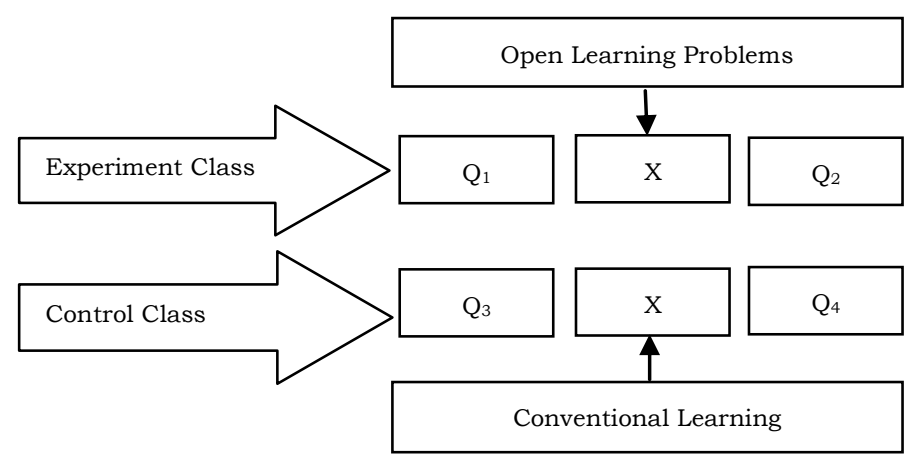

classes as sample from research. Prior to sampling, homogeneity tests were first performed to determine whether the sample group was homogeneous or not. If it is known that the sample group is homogeneous, then sampling is done by cluster sampling technique (Area Sampling). In this study the material used is the subject of building space especially in the sub subject of the cube and the beam. Based on the types and variables of the research above, then using the research design is "pretest-posttest control group design" (Sugiyono, 2010: 112).

\section{Information:}

$\mathrm{O}_{1}$ : pretest for the experimental class

$\mathrm{O}_{2}$ : postest for the experimental class

$\mathrm{O}_{3}$ : pretest for control class

$\mathrm{O}_{4}$ : postest for control class

$\mathrm{X}$ : treatment

Fig 1. Pre-test-post-test control group design

The instrument used is test problem. Problem test is the questions given to students to know the level of student ability after following the learning process. In this research about the test that will be given to the students is a matter of essay test (description) which consists of 5 problems in the form of open matter model of subject matter wake subspace space discussion of cubes and beams. The test in this study was conducted twice in the beginning and at the end. Pre-test is a test done at the beginning of the learning, post-test is a test done at the end of learning. Problem test used is a matter of tests that have met certain requirements are: validity, reliability, distinguishing power, and the level of difficulty.

\subsection{Validity}

Validity is a measure that indicates the level of validity or validity of an instrument. Validity used is the test of construct validity (construct validity). After the data obtained from the test results, then the test of construct validity is done by factor analysis, that is by correlating between instrument item scores with Pearson Product Moment formula. As follows.

$$
r_{X Y}=\frac{N \sum X Y-\left(\sum X\right)\left(\sum Y\right)}{\sqrt{\left\{N \sum X^{2}-\left(\sum X\right)^{2}\right\}\left\{N \sum Y^{2}-\left(\sum Y\right)^{2}\right\}}}
$$

(Arikunto, 1998:162)

Information:

$\mathrm{r}_{\mathrm{xy}} \quad=$ Correlation coefficient,

$\mathrm{n} \quad=$ Number of respondents,

$\Sigma \mathrm{X}=$ Number of test class scores 1 ,

$\sum \mathrm{Y} \quad=$ Number of test class scores 2 ,

$\Sigma \mathrm{XY}=$ Total multiolication of test scores 1 class and test class 2 ,

$\Sigma \mathrm{X}^{2}=$ The sum of squares of test grade scores 1 ,

$\Sigma \mathrm{Y}^{2}=$ Quantity of test scores class size 2 .

Next is calculated by t-test with the formula: $t_{\text {count }}=\frac{r \sqrt{n-2}}{\sqrt{1-r^{2}}}$ Where:

$\mathrm{t} \quad=$ Value $\mathrm{t}$ count

$r \quad=$ Coefficient of correlation $r$ count

$\mathrm{n} \quad=$ Number of respondents
Distribution (Table $\mathrm{t}$ ) for $\mathrm{a}=0.05$ and degrees of freedom $(\mathrm{dk}=\mathrm{n}-2)$.

Rule of applicability:

a) If $t$ count $>t$ table means valid

b) If $t$ count $<t$ table means not valid

Table 1. Criteria of validity

\begin{tabular}{cc}
\hline Limitations & Criteria \\
\hline $0.80<r x y \leq 1.00$ & Very high \\
\hline $0,60<r x y \leq 0,80$ & High \\
\hline $0,40<r x y \leq 0,60$ & Enough \\
\hline $0,20<r x y \leq 0,40$ & Low \\
\hline$r x y \leq 0.20$ & Very low \\
\hline
\end{tabular}

(Ruseffendi, 1998: 144)

\subsection{Reliability}

According to Arikunto (1998: 170) "reliability refers to a sense that an instrument can be trusted to be used as a data-gathering tool because the instrument is already good". The formula used in the reliability test is by using the Alpha method with the reason that this formula can be used to test a test question in the form of a test description where the score per item because different. Testing formula using Alpha method as follows:

$$
r_{11}=\left[\frac{k}{k-1}\right]\left[1-\frac{\sum s_{i}}{S_{t}}\right]
$$

Where:

$\mathrm{r} 11=$ Value of reliability

$\mathrm{k}=$ Number of items

$\sum S_{\mathrm{i}}=$ Number of variance score of each item

$\mathrm{S}_{\mathrm{t}} \quad=$ Variance Total

Result of $r_{11}$ then consulted with $r_{\text {table }}$ with $\mathrm{dk}=\mathrm{N}-1$, and significant $0,05(5 \%)$. Rule of applicability:

a. If $r_{11}>r_{\text {table }}$ means reliable.

b. If $r_{11}<r_{\text {table }}$ means not reliable (Riduwan, 2010:118). 
Tabel 2. Criteria of reliability

\begin{tabular}{cc}
\hline Limitations & Criteria \\
\hline$r_{11} \leq 0,20$ & Very Low \\
\hline $0,20<r_{11} \leq 0,40$ & Low \\
\hline $0,40<r_{11} \leq 0,70$ & Enough \\
\hline $0,70<r_{11} \leq 0,90$ & High \\
\hline $0,90<r_{11} \leq 1,00$ & Very High \\
\hline
\end{tabular}

(Ruseffendi, 1998: 144)

\subsection{Differentiating power}

Differentiating power is the ability of a problem to distinguish between clever students and students who are not smart. The differentiating power can be calculated using the following formula:

$$
D P=\frac{S_{A}-S_{B}}{\frac{1}{2} n \cdot \max } \quad(\text { Jihad and Haris, 2008: 189) }
$$

Where:

$\mathrm{DP} \quad=$ Distinct Power

$\mathrm{S}_{\mathrm{A}} \quad=$ Number of top group scores

$\mathrm{S}_{\mathrm{B}} \quad=$ Number of bottom group scores

$\mathrm{n} \quad=$ Number of upper and lower group respondents

Maks = Maximum score of the question.

Tabel 3. Power distinguishing criteria

\begin{tabular}{cc}
\hline Limitations & Criteria \\
\hline $0.71-1.00$ & Very Good \\
\hline $0.41-0.70$ & Good \\
\hline $0.21-0.40$ & Enough \\
\hline $0.00-0.20$ & Less \\
\hline
\end{tabular}

Ruseffendi (in Jihad and Haris, 2008: 181)

\subsection{Level of difficulty}

A good test is a problem that has a difficulty level of tiered problems of easy, medium and difficult where it can be searched using the following difficulty formula:

Where:

$$
T K=\frac{S_{A}+S_{B}}{n \cdot \max }
$$

$\mathrm{TK}=$ Tabulation

$\mathrm{S}_{\mathrm{A}} \quad=$ Total upper group score

$\mathrm{S}_{\mathrm{B}} \quad=$ Total bottom group score

$\mathrm{n} \quad=$ Number of upper and lower group respondents

Max $=$ Maximum score of the question

(Jihad dan Haris, 2008: 182)

Tabel 4. Criteria for Tribune

\begin{tabular}{cc}
\hline Limitations & Criteria \\
\hline $0.71-1.00$ & Easy \\
\hline $0.31-0.70$ & Medium \\
\hline $0.00-0.30$ & Hard \\
\hline
\end{tabular}

Sudjana (in Jihad and Haris, 2008: 182)

\subsection{Homogeneity test}

Zainal Arifin (2011:286) suggests the purpose of homogeneity test is to know whether the second variance of the sample data homogeneous or not. To know whether or not the variance of the samples the researchers used the homogeneity test by taking data from the daily test value on the previous material.The steps for testing homogeneity are as follows:
1. Determine the variance with the following formula:

$$
F_{\text {coun: }}=\frac{\text { Greatest variance }}{\text { Smallest variance }}
$$

2. Comparing the value of $\mathrm{F}_{\text {count }}$ with $\mathrm{F}_{\text {table, }}$

$\mathrm{F}$ tablecan be obtained by the formula dk numerator $=\mathrm{n}-1$ (Greatest Variance) and $\mathrm{dk}$ denominator $=\mathrm{n}-1$ (Smallest Variance) and to a significant extent $(\alpha)=0.05$. To conclude the comparison as follows:

If $\mathrm{F}_{\text {count }} \leq \mathrm{F}_{\text {table }}$, then homogeneous

If $F_{\text {count }} \geq F_{\text {table }}$, then it is not homogeneous (Riduwan, 2004:120).

3. Conduct a T-test using the following formula:

a. If the variance is the same (homogeneous) $\mu_{1}=\mu_{2}$, the formula used is:

$t=\frac{\bar{x}_{1}-\bar{x}_{2}}{s \sqrt{\frac{1}{n_{1}}+\frac{1}{n_{2}}}}$ with $s^{2}=\frac{\left(n_{1}-1\right) s_{1}{ }^{2}+\left(n_{2}-1\right) s_{2}{ }^{2}}{n_{1}+n_{2}-2}$

$t_{\text {table }}=t_{\left(n_{1}+n_{2}-2\right)}$, where the degree of $(d b)=\left(n_{1}+n_{2}-2\right)$ and a significance level of 0.05 .

b. If the variance is not same (is not homogeneous) $\mu_{1} \neq \mu_{2}$, the formula used is:

$$
t=\frac{\bar{x}_{1}-\bar{x}_{2}}{\sqrt{\frac{s_{1}^{2}}{n_{1}}+\frac{s_{2}^{2}}{n_{2}}}}
$$

$t_{\text {table }}=t_{\left[(1-n)\left(n_{1}+n_{2}-2\right)\right]}$ where the degree of $(\mathrm{db})=\left(\mathrm{n}_{1}\right.$ $+n_{2}-2$ ) and a significance level of 0,05. To conclude the comparison: If $t_{\text {count }} \leq t_{\text {table }}$, then homogeneous and If $t_{\text {count }} \geq t_{\text {table }}$, then it is not homogeneous.

(Sugiyono, 2007: 138)

\subsection{Data normality test}

Zainal Arifin (2011: 287) said that "the amount of data above 30, so no need to test the data normality". So in this study the researchers did not use the normality test because the number of students in class VIII SMP Al Badri Arjasa Jember each class more than 30 students.

\subsection{Data analysis techniques}

After testing the similarity of variance, then to know the difference of learning result between experiment class and control class using formula with the following conditions:

a. If both samples have the same variant.

$$
\begin{aligned}
& \mathrm{H}_{0}: \mu_{1}=\mu_{2} \\
& \mathrm{H}_{1}: \mu_{1} \neq \mu_{2}
\end{aligned}
$$

By using the formula:

$$
\mathrm{t}=\frac{\overline{\mathrm{x}}_{1}-\overline{\mathrm{x}}_{2}}{\mathrm{~S} \sqrt{\frac{1}{\mathrm{n}_{1}}+\frac{1}{\mathrm{n}_{2}}}}
$$

With standard sample deviation $(\mathrm{S})$ :

$$
s=\sqrt{\frac{\left(n_{1}-1\right) S_{1}^{2}+\left(n_{2}-1\right) S_{2}^{2}}{n_{1}+n_{2}-2}}
$$

Information :

$\mathrm{t} \quad=\mathrm{T}$-test value sought

$\overline{\mathrm{x}}_{1} \quad=$ Group average 1

$\overline{\mathrm{x}}_{2} \quad=$ Group average 2

$\mathrm{s} \quad$ Composite raw deviation

$\mathrm{S}_{1}^{2}=$ Standard deviation of sample 1 squared (variance 1 ) 
$\mathrm{S}_{2}^{2}=$ Standard deviation of sample 2 squared (variance 2)

$\mathrm{n}_{1}=$ Number of samples 1

$\mathrm{n}_{2}=$ Number of samples 2

By the criterion $\mathrm{H}_{0}$ is accepted if $-t_{1-\frac{1}{2} \alpha}<t<t_{1-\frac{1}{2} \alpha}$,

where $t_{1-\frac{1}{2} \alpha}$ is obtained from the distribution list $t$ with

$\mathrm{dk}=\left(\mathrm{n}_{1}+\mathrm{n}_{2}-2\right)$ and probability $\left(1-\frac{1}{2} \alpha\right)$ And with a

real level (a) 0.05 (5\% error rate).

b. If both groups have unequal variants.

$\mathrm{H}_{0}: \mu_{1}=\mu_{2}$

$\mathrm{H}_{1}: \mu_{1} \neq \mu_{2}$

By using the formula:

By the criterion $\mathrm{H}_{0}$ is accepted if:

$-\frac{w_{1} t_{1}+w_{2} t_{2}}{w_{1}+w_{2}}<t^{\prime}<\frac{w_{1} t_{1}+w_{2} t_{2}}{w_{1}+w_{2}} \quad$ with $\quad w_{1}=\frac{s_{1}^{2}}{n_{1}}$

$w_{1}=\frac{s_{2}^{2}}{n_{2}}, t_{1}=t_{\left(1-\frac{1}{2} \alpha\right),\left(n_{1}-1\right)}, t_{2}=t_{\left(1-\frac{1}{2} \alpha\right),\left(n_{2}-1\right)}$

$\mathrm{H}_{0}$ : There is no difference of mathematics learning result by using open learning model model and conventional learning model on the subject of building space in grade VIII Junior High School Al Badri Arjasa Jember.

$\mathrm{H}_{1}$ : There are differences in mathematics learning outcomes using open-ended learning model and conventional learning model on the subject of building space in grade VIII Junior High School Al Badri Arjasa Jember.

\section{RESULTS AND DISCUSSION}

The initial activity of the study started with pre-test in the experimental class and control class, then the next meeting was the giving of materials, where the researcher taught using the open-ended learning model in the experimental class and taught using the conventional learning model in the control class. Giving material done four times, each material is given 2 hours lesson $2 \times 40$ minutes. And the last meeting in the form of post-test in the experimental class and control class.

\subsection{Results of pre-test}

Before the students get the treatment done homogeneity test first with the data used is the result of pre-test. The pre-test for the experimental class and the control class was performed on February 05, 2018. The questions used in the pre-test will also be used for the post-test, the five tested questions, the test questions.

\section{Question (Pre-test \& Post-test)}

1. Given the length of the entire rib of the beam is $64 \mathrm{~cm}$, specify the length, width and height of the beam?

2. Eyla wants to create 8 skeleton beams made of wire. If the available wire is only $768 \mathrm{~cm}$, then how many length, width and height of the beam may Eyla make?

3. Watch the PQRS.TUVW beam on the side! If known volume $640 \mathrm{~cm} 3$. Calculate the length of $P Q, Q R, R V$ and the surface area of the block!

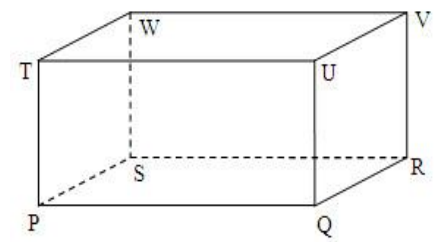

4. Given $\mathrm{ABCD}$.EFGH beam with $\mathrm{AB}=2 \mathrm{x} \mathrm{cm}, \mathrm{BC}=(\mathrm{x}+1)$ $\mathrm{cm}$, and $\mathrm{BF}=\mathrm{x} \mathrm{cm}$. If you want to fill the beam with water volume less than $500 \mathrm{~cm} 3$. Determine the value of $\mathrm{x}$ and what size of the beam you will make?

5. A large box shaped beam length of $27 \mathrm{~cm}$, width $10 \mathrm{~cm}$, and height $8 \mathrm{~cm}$. If the big box will be filled by a few small boxes in the shape of a cube, then determine the length of the cube's ribs!

The lowest value in the control class is 5 and the highest value is 55 then for the experimental class the lowest value is 10 and the highest value is 51 . For more details can be seen in table 5 below.

Table 5. Values of pre-test of experimental and control class students

\begin{tabular}{clcc}
\hline No & Component & $\begin{array}{c}\text { Class of } \\
\text { Experiment } \\
\text { VIII-A }\end{array}$ & $\begin{array}{c}\text { Class of } \\
\text { Control } \\
\text { VIII-B }\end{array}$ \\
\hline 1 & Number of Students & 35 & 35 \\
\hline 2 & Lowest Value & 10 & 5 \\
\hline 3 & Top Rated & 51 & 55 \\
\hline 4 & Average Score & 30,629 & 28,714 \\
\hline 5 & Varians & 108,887 & 199,445 \\
\hline 6 & Standard Deviation & 10,435 & 14,123 \\
\hline
\end{tabular}

Based on the results of analysis and calculation, the pre-test values of the experimental class and control classes are normal and homogeneous distributed. The first data to be compared is the average pre-test value between the experimental class and the control class, for the experimental class, the average value is 30,629 and the control class is 28,714 . The variants for the experimental class obtained 108,887 and control class 199,445.

\subsection{Determination of research respondents}

The data used to test homogeneity is the value of mathematical repetition of all students of class VIII.Furthermore, to determine the class pairs to be used as research respondents conducted drawing techniques on homogeneous classes. From the draw results obtained pair of class VIII-A and VIII-B as respondents research. In order to determine the experimental and control classes, a drawing of the classes VIII-A and VIII-B was conducted. Based on the result of the draw of the selected class VIII-A as the experimental class and VIII-B as the control class. The number of VIII-A and VIII-B students before and after the pre-test and post-test were 35 students. So the number of Respondents in this study is 70 students. 


\subsection{Homogeneity test}

The results of the homogeneity test can be seen in table 6 and table 7 below.

Table 6. Homogeneity test of pre-test experiment and control class

\begin{tabular}{cccccccccc}
\hline No. & Class & $\mathrm{N}$ & Average & Standard Deviasi & Varian & $\mathrm{F}_{\text {count }}$ & $\mathrm{F}_{\text {table }}$ & $\mathrm{T}_{\text {count }}$ & $\mathrm{t}_{\text {table }}$ \\
\hline 1 & VIII-A & 35 & 30,629 & 10,435 & 108,887 & \multirow{2}{*}{1.832} & \multirow{2}{*}{1.776} & \multirow{2}{*}{0,645} & \multirow{2}{*}{1,999} \\
\hline 2 & VIII-B & 35 & 28,714 & 14,123 & 199,445 & & & & \\
\hline
\end{tabular}

Based on the description on the homogeneity test table, the pre-test grade of the experimental class and the control class according to the rules of the applicable decision, it can be concluded that the experimental and control classes are not homogeneous.

Table 7. Homogeneity test of post-test experiment and control class

\begin{tabular}{|c|c|c|c|c|c|c|c|c|c|}
\hline No & Class & $\mathrm{N}$ & Average & Standard Deviasi & Varian & $F_{\text {count }}$ & $F_{\text {table }}$ & $\mathrm{T}_{\text {count }}$ & ttable \\
\hline 1 & VIII-A & 35 & 69,637 & 25,137 & 631,879 & \multirow{2}{*}{1.529} & \multirow{2}{*}{1.776} & \multirow{2}{*}{2,337} & \multirow{2}{*}{1.999} \\
\hline 2 & VIII-B & 35 & 56,886 & 20,332 & 413,398 & & & & \\
\hline
\end{tabular}

Based on the description on the homogeneity test table, the post-test grade of the experimental class and the control class adjusted to the applicable decision rule, it can be concluded that the experimental class and control class are not homogeneous.

\subsection{Results of post-test}

Post-tests for the experimental class and control classes were conducted on Monday, February 26, 2018. The lowest score on the control class is 23 and the highest value is 100 and then for the experimental class the lowest value is 40 and the highest value is 100. For more details, seen in Table 8 below:

Table 8. Comparison of post-test results of experimental and control class students

\begin{tabular}{clcc}
\hline No & Componen & $\begin{array}{c}\text { Class of } \\
\text { Experiment } \\
\text { VIII-A }\end{array}$ & $\begin{array}{c}\text { Class of } \\
\text { Control } \\
\text { VIII-B }\end{array}$ \\
\hline 1 & Number of Students & 35 & 35 \\
\hline 2 & Lowest Value & 40 & 23 \\
\hline 3 & Top Rated & 100 & 100 \\
\hline 4 & Average Score & 69,657 & 56,886 \\
\hline 5 & Varians & 631,879 & 413,398 \\
\hline 6 & Standard Deviation & 25,137 & 20,332 \\
\hline
\end{tabular}

Furthermore, based on the results of the analysis and the calculation results obtained that the value of post-test experimental class and control class distributed normal and not homogeneous. For the experimental class obtained an average value of 69.657 and for the control class obtained an average value of 56.886 , while the variant for the experimental class obtained value 631,879 and control class 413,398 . Then after obtained the calculation proceed to answer the hypothesis proposed. The calculations were performed by using t-test analysis, compared to the post-test of the experimental group and the control group. Obtained $t$ - count is 3.337 and $t$ - table is 1.999 for a significance level of $5 \%$ based on the result it can be said that $t$ - count $>t$ - table. In accordance with the criteria if $\mathrm{t}$ - count $>\mathrm{t}$-table then $\mathrm{H}_{0}$ rejected and $\mathrm{H}_{1}$ accepted. This means, there are differences in mathematics learning outcomes by using the model of learning about open problems and conventional learning model on the subject of building space in class VIII Junior High School Al Badri Arjasa Jember.

\section{CONCLUSION}

Based on the results of research, hypothesis testing and discussion can be concluded as follows:

a. There are differences in mathematics learning outcomes by using open-ended learning model and conventional learning model on the subject of building space in Grade VIII of Junior High School Al Badri Arjasa Jember.

b. Learning model of open matter is suitable to be applied to the subject of wake up space in class VIII Junior High School Al Badri Arjasa Jember.

\section{ACKNOWLEDGEMENTS}

Thanks to Al Badri Arjasa Jember School who has given permission to do research.

\section{REFERENCES}

Asmedy. 2012. Development Of Learning Tools Logic With Open Ended Approach In Class X High School. Thesis not published. Surabaya: UNESA Graduate Program.

Arikunto, S. 1998. Research Procedure A Practice Approach (Revised Edition IV). Jakarta: PT Rineka Cipta.

Arifin, Z. 2011. Educational Research Methods and New Paradigm. Bandung: ROSDA.

Fonna, M., \& Mursalin, M. (2018). Role of Self-Efficacy Toward Students' Achievement in Mathematical Multiple Representation Ability (MMRA). Jurnal Ilmiah Peuradeun, 6(1), 31-40.

Hudojo, H. 1990. Development of Curriculum And Mathematics Learning. Malang: State University of Malang.

Tampomas, H. 2005. Mathematics 3 For SMP/MTs Class IX. Jakarta: Yudhishthira.

Mahmudi. A. 2008. Developing Open-Ended Problems in Mathematics Learning, (Online),

(http://staff.uny.ac.id/sites/default/files/penelitian/Ali Mahmudi, S.Pd, M.Pd, Dr./Makalah 02 PIPM 2008_ExecutingSoal Open_.pdf, accessed 4 December 2017).

Ruseffendi. 1998. Fundamentals of Education Research and Other Non-Exact Areas. Semarang: IKIP Semarang.

Soedjadi, R. 2000. Tips on Mathematics Education in Indonesia. 
Jakarta: Ministry of National Education.

Sugiyono. 2007. Statistics For Research. Bandung: ALFABETA.

Sugiyono. 2010. Educational Research Methods. Bandung: ALFABETA.

Basleman, A. \& Mappa, S. 2011. Adult Learning Theory. Bandung: PT

Remaja Rosdakarya.

Sudjana. 2005. Statistical Method. Bandung: TARSITO.

Riduwan. 2010. Learn Easy Research For Teachers-Employee and Beginner Researcher. Bandung: ALFABETA.

Jihad \& Haris. 2010. Evaluation of Learning. Yogyakarta: Multi Pressindo.

National Education Standards Agency. 2006. KTSP And Assessment of Competence Based Mathematics Learning. Jakarta: BSNP. 